\title{
Social stratification \\ under tension in a globalized era
}

\section{Emilio Klein \\ Sociologist, Multidisciplinary \\ Technical Team, \\ International Labour \\ Organization (ILO), \\ Santiago, Chile \\ klein@oitchile.cl}

Víctor Tokman

Regional Director for

the Americas,

ILO, Santiago, Chile

tokmansc@oitchile.cl
The objective of this paper is to explore the effects of globalization on the labour market and social stratification. It is generally held that globalization will bring about progress for nations and people. This, however, is far from clear, since the experience of almost two decades has been raising increasing doubts about the potential net gains and, particularly, the distribution of such gains. Clearly, there are winners and losers among both countries and people. We will concentrate on the effects upon people within countries and refer only to one region: Latin America. Our aim is to identify winners and losers in the globalization process and, particularly, the impact on social stratification. Is globalization leading towards greater social integration within nations, or is social disintegration the result (because only some groups are being integrated, while a majority is progressively excluded)? To analyse this issue, the paper is structured into four parts. The first looks at globalization as an integral part of a policy compact, since it is necessary to consider the impact of the whole package rather than trying to isolate partial effects. The second concentrates on the effects on employment, incomes and equity. The third explores changes in the social structure associated with some of the main processes accompanying globalization. Lastly, we draw some conclusions about the social structure of Latin America during the reform period. 


\section{I \\ Globalization as part of a policy compact}

Globalization in a restricted sense refers to major changes in trade, finance and information that have taken place in the international economy. This process has not happened in isolation, but as an integral part of a policy package combining internal adjustment measures with changes in the way countries relate to the international economy. Three main processes characterize the emerging situation: globalization, privatization and deregulation (Tokman, 1997). The policy compact followed by most countries, at least in Latin America, came to be known after 1989 as the "Washington Consensus" (Williamson, 1990).

Globalization means that national economies are now more integrated with the international economy and that goods, capital and communications, and also people, are closer together today than ever before in the past. This has been the result both of the opening up of economies and of rapid technological change. Trade and financial liberalization has come about through reductions in tariff and non-tariff barriers resulting from i) multilateral agreements in the General Agreement on Tariffs and Trade (GATT) and the creation of its successor, the World Trade Organization (wTO); ii) new or reactivated integration schemes, such as the North American Free Trade Agreement (NAFTA) and the South American free trade association known as Mercosur; iii) an explosion of bilateral trade agreements during recent years; and, most importantly, iv) unilateral tariff reductions as a key component of the adjustment policy package. Latin American tariffs decreased from an average of between 35\% and 100\% (minimum and maximum rates) in 1985 to between $14 \%$ and $22 \%$ in the early 1990 s. Diversification of the tariff structure has also been greatly reduced, and is now limited in most countries to three or fewer tariff categories (Tokman, 1999).

Globalization opens up new opportunities for growth and job creation, but at the same time affects the determinants of employment and wages and requires regulation to prevent unfair international competition.

$\square$ A preliminary version of this paper was prepared at the request of UNDP as a contribution to the Human Development Report, 1999.
For example, given the differences in factor endowment, it is expected that trade from developing to developed countries will largely consist of goods whose production involves intensive use of unskilled labour. This could increase the demand for workers of this type and decrease the gap between the wages of skilled and unskilled labour.

If this came about, though, it could combine with the differences in remuneration and labour regulations that obtain between countries to generate trade expansion based on unfair labour practices or increased exploitation of workers. The prospect has sparked an international discussion about how this outcome can be avoided and whether there is a need for additional regulation. While there has been no general agreement on how to proceed, it is clear that nobody postulates the equalization of wages between countries, since this would affect the competitive position of developing countries. Nor is it accepted that trade expansion should be based on labour exploitation. Trade sanctions for those who do not comply with minimum international labour standards have been mooted, but so far the idea has been ruled out because of the danger of their being misused as an instrument of trade protection. There is, however, more general agreement about the need for national and international monitoring to ascertain whether economic progress is being accompanied by social progress and, particularly, by compliance with basic labour standards among all trading partners. This has been incorporated into the International Labour Organization (ILO) Declaration on Fundamental Principles and Rights at Work and its Follow-up, adopted by the International Labour Conference on 18 June 1998.

Globalization also affects the determinants of job creation and wages because in open economies the ability to compete becomes a major factor and places constraints on wage adjustments. There now has to be a closer link between wages and productivity than there was in the old economic environment. In closed economies, wage increases in excess of productivity growth can be transferred to prices, resulting in inflation; in open economies, the outcome is a reduced capacity to 
compete. In addition, demand fluctuations mean that companies have to be able to adapt faster and show greater flexibility in production and labour processes.

Privatization is the second feature of the new economic environment. Privatization reduces the size and functions of government and increases the importance of the private sector and markets in the management and allocation of resources. Public-sector employment naturally falls, rationalization by the new owners reduces total employment and public-sector enterprises are transferred to national or international capitalists, the main motive being the need to reduce budget deficits during adjustment. Increasingly, furthermore, responsibility for investment is transferred to the private sector and public investment is limited to basic infrastructure and social sectors, with growing private-sector involvement in the execution and management of these.

Deregulation is the third process in this new environment. This has meant reducing protection and government intervention in trade, finance and labour markets. As was mentioned earlier, trade and financial liberalization are leading to increased globalization, while product and labour market protection is being reduced in order to increase economic efficiency and enable markets to play a greater role in the allocation of resources. The deregulation process has in part been driven by substantial legal reforms, but there has also been a considerable de facto increase in flexibility brought about by the unfettered operation of markets.

The threefold process of globalization, privatization and deregulation is occurring in an international environment characterized by "universalization" of economic and social problems and by increased ideological homogeneity. Today, employment problems and social exclusion are no longer to be found solely in developing countries, but constitute a major challenge even in the more developed economies of the world. Unemployment in some of the industrialized countries of the Organisation for Economic Co-operation and Development (OECD) is stubbornly high; more than 30 million people are officially classified as unemployed, while a further 10 million are no longer actively seeking work (OECD, 1994 and ILO, 1996). The average rate of unemployment exceeds $10 \%$ and in the case of some vulnerable groups, like young people, one in five is jobless in many countries. The end of the Cold War broke down ideological barriers, and today's conflicts are caused less by ideological divergence and more by local interests or by a natural reaction against the social cost of adjustment.
The three processes are interrelated in both practical and analytical terms. On the analytical side, globalization could not have advanced had it not been accompanied by the other components of adjustment that reduced trade protection, as well as by financial liberalization and privatization with all the opportunities these opened up for increased trade, capital flows and foreign direct investment. All these policies contributed to the attainment of macroeconomic balance, but they were also necessary conditions for integration into the world economy. These sets of policies were fully incorporated into the Washington Consensus, together with instruments designed to help secure fiscal discipline. The latter were included with the main objective of ensuring price stability, but they also play an important role in creating incentives for capital inflows in a framework of greater stability. Indeed, the one thing that has not been liberalized is the movement of unskilled workers. Some retrospective policies regularizing illegal migration have been introduced, but closed borders, or at least tight regulation of flows, continue to be the rule.

The recent economic history of Latin American countries shows that, in practice, globalization has been accompanied by privatization and deregulation. The timing and policy mix has varied according to country and it is perhaps premature to evaluate the results. Only five countries -Brazil, Chile, Colombia, Costa Rica and Uruguay- have attained a per capita income level higher than in the pre-crisis period. Even fewer have achieved a high and sustained rate of growth, Chile and Colombia being the only countries that have been able to expand at more than $5 \%$ a year for four consecutive years. Growth rates have been erratic and stop-go cycles have been the norm. In addition, other factors have influenced performance. Initial conditions were different in each country: some started the reform process early, others only in the late 1980 s or early 1990s. The policy mix at each stage was also different.

In spite of the differences, after a decade and a half of adjustment it can be concluded that all Latin American countries have been involved in the globalization and adjustment process, and that privatization and deregulation have been an integral part of the policy compact. The results are still unclear and policy instruments are continually evolving, but it is plain that the region is today more open and integrated into the world economy, more privatized and less regulated than it was before 1980. All these things have happened simultaneously; hence, any analysis of results should take account of the context. This is what we shall do in the rest of this paper. 


\section{II}

\section{Employment, incomes and equity under globalization}

\section{The effects anticipated}

Globalization is expected to have two main effects on labour and incomes. Firstly, productivity gains, particularly in tradable sectors, should result in increased employment and lower prices in those sectors. The latter should also result in improved real incomes and welfare for the population. Secondly, increased wages in export sectors, assumed to be more intensive in unskilled labour, should result in a reduction of wage differentials by skill level and, hence, in increased equity.

The reduction or elimination of tariffs and nontariff barriers should lead to a fall in the relative prices of tradable goods. This would result, on the production side, in factors being reallocated to export sectors and, on the consumption side, to expenditure being reallocated to imported goods and services. Consequently, there should be a positive effect on employment resulting from export growth, while reductions in the relative prices of importable goods should lead to an increase in real incomes. Trade liberalization should therefore result in increased welfare.

In the short run, however, the employment growth resulting from increased exports could be offset by a decrease in employment in sectors that compete with imports. Increased competition in these sectors forces enterprises to increase productivity, generally at the expense of employment. The net employment effect of economic opening will depend on the demand for labour in both tradable and non-tradable sectors and on labour supply dynamics. This, in turn, will affect average wages in each sector.

Another anticipated result of trade liberalization is that it will lead to a rise in the relative prices of developing country goods whose production involves intensive use of unskilled labour. This would lead to an increase in the demand for unskilled workers and a rise in their relative wages. As a consequence, wage dispersion would diminish. ${ }^{1}$

\footnotetext{
${ }^{1}$ For a discussion of the theoretical foundations of this expectation and its empirical validity in developed countries see, among others, Bhagwati and Dehejia (1993), Lawrence and Slaughter (1993), Wood (1994), ILO (1995) and Sachs and Shatz (1994).
}

\section{The results in practice}

a) Productivity gains and international competitiveness

The first of the expected outcomes that is actually observed in most countries is productivity growth in tradable sectors, particularly manufacturing industry. As will be seen below, this outcome is associated with a reduction in the employment level of the sector. During the 1990s, productivity per employee expanded at annual rates of between 5\% and 7\% in Argentina, Brazil, Mexico and Peru, while the rate was about $3 \%$ in Chile.

The effects on international competitiveness vary depending on the country studied and the indicators used to measure labour costs. It is usually argued that overpriced labour can affect access to international markets, and in a more competitive environment costs do indeed matter. Overpriced labour can be the result of higher wages or high non-wage labour costs or both. The situation in most Latin American countries does not seem to justify the priority given to this issue (except for some necessary adjustments).

Although they have recently recovered somewhat, wages in most Latin American countries are still lower than in 1980. Minimum wages were $26 \%$ lower on average in 1999 than in 1980, but wages in manufacturing industry rose by $2.9 \%$ in the same period. Nonwage labour costs vary from country to country, ranging from $38 \%$ to $64 \%$ of wages. In the case of Chile and Argentina, non-wage labour costs are higher than in Korea, similar to those of the United States, and much lower than those prevailing in European OECD countries. Hourly labour costs in Latin American manufacturing industry range from US\$2.10 to US\$ 6.50 ; this is between one third and one eighth of the United States level and less even than in the South-East Asian countries. Labour cost differences per unit of output are smaller due to higher productivity in competing countries (table 1). This shows what a high priority has to be given to raising productivity, as opposed to merely cutting costs, if competitiveness is to be improved (Tokman and Martínez, 1999).

The fact that relative labour costs are not high does not mean there is no scope for making adjustments to the labour cost structure to reduce them further and, 
TABLE 1

Selected countries: Labour costs and international competitiveness ${ }^{a}$

\begin{tabular}{|c|c|c|c|c|c|c|c|c|c|c|}
\hline & \multirow{3}{*}{$\begin{array}{l}\text { Hourly } \\
\text { wage } \\
\text { (dollars) }\end{array}$} & \multirow{3}{*}{$\begin{array}{l}\text { Non-wage } \\
\text { labour costs } \\
\text { as } \% \text { of wages }\end{array}$} & \multirow{3}{*}{$\begin{array}{l}\text { Hourly cost } \\
\text { of labour } \\
\text { (dollars) }\end{array}$} & \multirow{3}{*}{$\begin{array}{c}\text { Labour costs } \\
\text { per unit of } \\
\text { output } \\
\text { (United States }=100 \text { ) }\end{array}$} & \multicolumn{6}{|c|}{ Annual changes 1990-1995 } \\
\hline & & & & & \multicolumn{2}{|c|}{$\begin{array}{c}\text { Labour } \\
\text { costs }\end{array}$} & \multirow[t]{2}{*}{$\begin{array}{l}\text { Produc- } \\
\text { tivity }\end{array}$} & \multicolumn{3}{|c|}{ Competitiveness $^{\mathrm{b}}$} \\
\hline & & & & & $\mathrm{A}$ & B & & $\bar{A}$ & B & $\overline{\mathrm{C}}$ \\
\hline Argentina & 4.6 & 42.5 & 6.5 & 55 & -2.0 & 13.1 & 7.0 & 9.2 & -6.1 & 3.7 \\
\hline Brazil & 3.7 & 58.2 & 5.9 & 60 & 2.9 & 8.5 & 7.5 & 4.5 & -0.9 & 4.3 \\
\hline Chile & 2.5 & 38.0 & 3.5 & 43 & 4.3 & 9.4 & 3.2 & -1.1 & -5.7 & 5.9 \\
\hline Mexico & 1.9 & 42.0 & 2.8 & 47 & 1.2 & 1.5 & 5.2 & 4.0 & 3.6 & na \\
\hline Peru & 1.3 & 64.3 & 2.1 & 43 & 5.1 & 11.6 & 6.6 & 1.4 & -4.5 & 0.3 \\
\hline United States & 12.6 & 40.3 & 17.7 & 100 & & 2.6 & 3.8 & & -1.2 & na \\
\hline Germany & 16.1 & 78.5 & 28.7 & 150 & & 2.1 & 1.8 & & -0.3 & na \\
\hline Republic of Korea & 6.8 & 21.9 & 8.2 & 60 & & 3.6 & 11.9 & & 8.0 & 50.0 \\
\hline
\end{tabular}

Source: Tokman and Martínez (1999), ILO (1998) and updating by authors.

a Manufacturing industry, circa 1997. Competitiveness is defined as the difference between changes in productivity and labour costs.

b A $=$ Changes in local currency at constant prices, deflated by consumer price index (1990-1995).

$\mathrm{B}=$ Changes in dollars (1990-1995).

$\mathrm{C}=$ Changes in dollars between July 1997 and June 1998.

particularly, to lower the cost of unskilled labour. Taxes on unskilled workers tend to reduce employment, while some of the existing taxes on the wage bill would be more efficient if they were transferred to other sources of revenue, particularly those that go to finance housing or other investments.

The evolution of labour costs in the 1990s also throws up other policy issues for consideration. Labour costs deflated by consumer prices have not increased ahead of productivity, for instance, in Argentina, Brazil, Mexico or Peru, and have thus been no impediment to increased access to international markets. However, when expressed in dollars rather than local currency, or when observed in relation to producer prices, the gains are slighter, and in most cases competitiveness has declined (table 1). This is due to the effects of macroeconomic policy during the period, as in most countries this involved national currencies being kept overvalued owing to the need to reduce inflation and to the liberalization of capital flows. Part of the decline is explained by delays in adjusting the exchange rate.

Meanwhile, domestic prices adapt at differing speeds to a more competitive economic environment: prices for traded goods, generally included in producer prices, adjust relatively quickly, while those for consumer goods, which are more influenced by non-traded goods and services, tend to be slower in adjusting. The result is that while labour costs expressed in consumer price terms did not rise, they actually increased very fast in relation to producer prices. This change in relative prices, while it lies outside the labour market sphere, does influence the dynamics of wage determination because it leads to the outlook of workers (based on the purchasing power of wages) diverging from that of those who operate businesses (based on profit margins).

Furthermore, as the situation after mid-1997 clearly illustrates, competitiveness is also dependent on developments in other countries. Despite a rise of between $0.4 \%$ and $10 \%$ in the competitiveness of Latin American countries, their ability to compete with goods from the Asian countries deteriorated. Competitiveness gains in these countries were about $50 \%$-ranging from $20 \%$ in Thailand to $60 \%$ in Malaysia- while among Latin American countries the largest increase, in Colombia, was about $10 \%$.

To sum up, productivity grew, as expected, as a consequence of the reform process, but some adjustments are still needed. Firstly, if international competitiveness is to be maintained, non-wage labour costs need to be examined. Secondly, macroeconomic policies, particularly overvalued exchange rates and relative prices, should be reviewed. Lastly, productivity gains have been insufficient to close the gap with competitors.

\section{b) Job creation}

A second effect of globalization has been inadequate job creation in relation to the rapid increase in the economically active population (EAP). On average, the nonagricultural EAP has grown by over $3 \%$ a year, partly as a result of increasing female participation in the wage economy (table 2). Job creation has lagged due to slow 
TABLE 2

Latin America: Economic activity, employment, wages and poverty

(Annual growth rates and index)

\begin{tabular}{|c|c|c|c|c|c|}
\hline Indicator & 1980 & 1985 & 1990 & 1995 & 1999 \\
\hline \multicolumn{6}{|l|}{ Economic activity } \\
\hline $\mathrm{GNP}^{\mathrm{a}}$ & $\ldots$ & 0.6 & 1.9 & 2.9 & 0.0 \\
\hline GNP per capita ${ }^{a}$ & $\ldots$ & -1.6 & -0.1 & 1.1 & -1.8 \\
\hline Inflation $^{\mathrm{a}}$ & $\cdots$ & 134.8 & 487.5 & 287.5 & 9.8 \\
\hline \multicolumn{6}{|l|}{ Population and employment } \\
\hline Population $^{\mathrm{a}}$ & $\ldots$ & 2.1 & 1.9 & 1.8 & 1.8 \\
\hline Total EAP ${ }^{a}$ & $\ldots$ & 3.5 & 3.1 & 2.6 & 2.6 \\
\hline Urban EAP (\%) & 66.9 & 70.0 & 72.8 & 75.3 & 76.6 \\
\hline Non-agricultural employment ${ }^{\mathrm{a}}$ & $\ldots$ & 3.5 & 4.4 & 3.0 & 2.8 \\
\hline Open unemployment rate & 6.7 & 10.1 & 8.0 & 7.2 & 8.8 \\
\hline Informal employment $(\%)^{\mathrm{b}}$ & 40.2 & 47.0 & 44.4 & 46.5 & 48.5 \\
\hline Public-sector employment $(\%)^{\mathrm{c}}$ & 15.7 & 16.6 & 15.5 & 13.4 & 13.0 \\
\hline \multicolumn{6}{|l|}{ Wages $^{\mathrm{d}}$} \\
\hline Real manufacturing wages & 100.0 & 93.1 & 86.6 & 92.9 & 102.9 \\
\hline Real minimum wages & 100.0 & 86.4 & 68.4 & 70.8 & 73.8 \\
\hline \multicolumn{6}{|l|}{ Poverty } \\
\hline Percentage of households in poverty $(\%)$ & 35.0 & 37.0 & 41.0 & 38.0 & 36.0 \\
\hline Urbanization of poverty $(\%)$ & 71.4 & $\ldots$ & 85.4 & 84.2 & $83.3^{\mathrm{e}}$ \\
\hline
\end{tabular}

Source: ILO, on the basis of national statistics.

a Annual growth rates.

b Percentage of urban employment.

c Percentage of total EAP.

d Index $1980=100$.

e 1997 figure.

and erratic economic growth. The result has been rising unemployment.

The average unemployment rate in Latin America rose from $6 \%$ in 1980 to $8.7 \%$ in 1983, i.e., during the first phase of adjustment. Unemployment fell from 1983 to 1992 , but never returned to its 1980 level. After 1992 unemployment grew continuously, reaching $8.8 \%$ in 1999. These developments reveal not only the limited capacity of the region's economies to bring down unemployment, but also increased vulnerability, since continuous adjustments entail a return to previous higher levels of unemployment. By 1999, Latin American unemployment had returned to the high levels of the mid1980s.

Four aspects should be taken into account in evaluating the way unemployment affects the people of Latin America. The first is that it can be misleading simply to compare the unemployment level with, for instance, the rates of over $10 \%$ prevailing in some OECD countries. Most countries lack unemployment insurance, and protection is generally occupation-linked. Joblessness means no income and no protection, and this is one of the main sources of social exclusion. Secondly, unem- ployment disproportionately affects women and young people. While the female unemployment rate is about $30 \%$ higher than the average, rates for young people are usually double the national figure. Unsurprisingly, women and young people account for a large proportion of the excluded. Thirdly, there are also large regional variations within countries. Adjustment tends to have a disproportionate effect on places where key sectors in need of restructuring are located. These activities generally constitute the main source of employment and production, and restructuring affects the whole region.

The situation also differs from country to country. Size, the degree of modernization attained and the stage reached in the reform process are determining factors in unemployment. Small, open economies are more vulnerable to external fluctuations and tend to have higher and more erratic unemployment rates than larger, more closed economies (where internal demand plays the biggest role and provides more autonomy). Again, in countries that have reached an advanced stage of urbanization and modernization, labour markets mainly adjust through unemployment, while in those with a 
large agricultural population or small formal sector, underemployment is the main adjustment variable. Lastly, the stage reached in the reform process also matters. Early reformers have been the most successful in reducing unemployment, while latecomers -particularly those that are now in the early phases of adjustmenttend to have higher and rising unemployment.

\section{c) Changes in the employment structure}

In addition to a higher unemployment rate, reform has brought about profound changes in the structure of employment. Four main interrelated processes can be identified: privatization, the shift from goods-producing sectors to services, the increase in informal working, and the loss of job security. These processes can be seen to have taken place in the 1990s, when most countries were already beyond or well advanced in the adjustment process.

Privatization introduced a major change in patterns of job creation in Latin America, owing to the role traditionally played by the public sector as the employer of last resort (something that will be discussed in the next section) and an important contributor to the development of the middle classes. Government did not directly contribute to employment growth in the 1990s. On the contrary, its share of urban employment fell in the region as a whole, from $15.5 \%$ in 1990 to $13.0 \%$ in 1999. This decrease does not include falls in publicsector employment that took place in earlier periods, as in Chile. This movement from public- to privatesector employment occurred in all countries, while in some -including Argentina, Costa Rica and Panamathe decline amounted to as much as five to ten percentage points.

The employment shift from the public to the private sector was a direct consequence of the privatization and deregulation processes accompanying globalization. State enterprises were transferred to the private sector and government functions were reduced. It was also one of the main results of fiscal discipline, an important component of stabilization policy. Budget deficits were generally reduced by cutting public expenditure, mostly the payroll, through a series of wage and employment cuts (table 3 ).

Generally speaking, however, the transfer of jobs was not towards larger private companies. Their share of total employment also declined over the same period, although at a slower pace than government employment. Between 1990 and 1998, the employment share accounted for by such companies fell from $40 \%$ to $39 \%$, the bulk of this decline taking place in countries such as Brazil, Colombia and Venezuela. If small enterprises are excluded, furthermore, the decline amounts to two percentage points (ILO, 1998). Large enterprises (more than 100 employees) were the most affected by trade liberalization and the need to increase productivity (mostly through employment reduction). Only 17 out of every 100 new jobs created during the 1990s were contributed by such companies. Increased labour flexibility facilitated adjustment, but at the cost of a more erratic employment level, as is clearly illustrated by the $1 \%$ decline in employment in large and medium-sized enterprises in 1998, when these firms had to adjust to increased competition from Asian products (figure 1).

The second of the processes referred to, the shift in employment from goods-producing sectors to services, was rapid in countries such as Bolivia, Costa Rica, Ecuador, Peru and Uruguay, where the share of manufacturing employment fell by between four and six percentage points during the 1990s.

In other countries the process was slower because restructuring was at a more mature stage (Chile) or a gradual approach was followed (Brazil and Colombia) or, in cases like Panama, because the economy was small and already open.

The new structural conditions resulting from the adjustment process have left these sectors more vulnerable to changes in competition. Manufacturing industry contracted in 1998 as a result of increased competition from Asian products. This contraction of output and employment was particularly large in food processing, textiles and clothing, shoes and machinery and equipment.

The shift of employment from manufacturing to services is partly the result of increased competition in a more open economy. Falling employment has been accompanied by rising productivity which, particularly in the short run, can only be achieved by cutting jobs. The effect has mainly been felt in urban employment, since agriculture, fishing and mining tend to contribute to employment growth during the liberalization process.

It cannot automatically be assumed that employment growth in the service sector means a shift towards low-productivity jobs. Some of the jobs created in the sector are in services that are integral to the modernization and globalization processes, such as finance, communications and trade. The productivity of these sectors is usually higher than that of manufacturing and can grow more rapidly. Unfortunately, this has not been 
TABLE 3

Latin America: Structure of urban employment, 1990 and 1998

(Percentages)

\begin{tabular}{|c|c|c|c|c|c|c|c|c|}
\hline \multicolumn{2}{|c|}{ Country and years } & \multicolumn{4}{|c|}{ Informal sector } & \multicolumn{3}{|c|}{ Formal sector } \\
\hline & & \multirow[t]{2}{*}{ Total } & \multirow[t]{2}{*}{$\begin{array}{l}\text { Own-account } \\
\text { workers }^{\mathrm{a}}\end{array}$} & \multirow[t]{2}{*}{$\begin{array}{l}\text { Domestic } \\
\text { service }\end{array}$} & \multirow[t]{2}{*}{$\begin{array}{c}\text { Micro- } \\
\text { enterprises }^{\mathrm{b}}\end{array}$} & \multirow[t]{2}{*}{ Total } & \multirow[t]{2}{*}{$\begin{array}{l}\text { Public } \\
\text { sector }\end{array}$} & \multirow[t]{2}{*}{$\begin{array}{c}\text { Small, medium- } \\
\text { sized and large } \\
\text { private } \\
\text { enterprises }^{\mathrm{c}}\end{array}$} \\
\hline \multicolumn{2}{|c|}{ Latin America } & & & & & & & \\
\hline \multirow{3}{*}{1990} & Total & 44.4 & 23.4 & 5.7 & 15.2 & 55.6 & 15.5 & 40.1 \\
\hline & Male & 41.2 & 22.8 & 0.5 & 17.9 & 58.8 & & \\
\hline & Female & 49.2 & 24.4 & 14.1 & 10.7 & 50.8 & & \\
\hline \multirow[t]{3}{*}{1998} & Total & 47.9 & 24.7 & 6.9 & 16.3 & 52.1 & 13.0 & 39.1 \\
\hline & Male & 45.0 & 24.9 & 0.6 & 19.6 & 55.0 & & \\
\hline & Female & 52.0 & 24.4 & 16.0 & 11.6 & 48.0 & & \\
\hline \multicolumn{9}{|c|}{ Argentina } \\
\hline \multirow[t]{3}{*}{1990} & Total & 52.0 & 27.5 & 5.7 & 18.8 & 48.0 & 19.3 & 28.7 \\
\hline & Male & 49.8 & 28.2 & 0.5 & 21.2 & 50.2 & & \\
\hline & Female & 55.5 & 26.5 & 14.3 & 14.7 & 44.5 & & \\
\hline \multirow[t]{3}{*}{1998} & Total & 49.3 & 22.7 & 6.4 & 20.3 & 50.7 & 12.7 & 38.0 \\
\hline & Male & 48.0 & 24.1 & 0.3 & 23.6 & 52.0 & & \\
\hline & Female & 51.4 & 20.4 & 15.8 & 15.2 & 48.6 & & \\
\hline \multicolumn{9}{|l|}{ Brazil } \\
\hline \multirow[t]{3}{*}{1990} & Total & 40.6 & 20.3 & 6.9 & 13.5 & 59.4 & 11.0 & 48.4 \\
\hline & Male & 36.1 & 19.6 & 0.5 & 16.0 & 63.9 & & \\
\hline & Female & 47.6 & 21.3 & 16.7 & 9.6 & 52.4 & & \\
\hline \multirow[t]{3}{*}{1998} & Total & 46.7 & 23.2 & 9.5 & 14.0 & 53.3 & 9.3 & 44.0 \\
\hline & Male & 43.0 & 25.1 & 1.0 & 16.8 & 57.0 & & \\
\hline & Female & 51.9 & 20.4 & 21.4 & 10.1 & 48.1 & & \\
\hline Chile & & & & & & & & \\
\hline 1990 & Total & 37.9 & 20.9 & 5.4 & 11.7 & 62.1 & 7.0 & 55.1 \\
\hline & Male & 33.5 & 21.3 & 0.2 & 12.0 & 66.5 & & \\
\hline & Female & 45.9 & 20.1 & 14.7 & 11.1 & 54.1 & & \\
\hline 1998 & Total & 37.5 & 18.5 & 5.1 & 13.9 & 62.5 & 7.2 & 55.3 \\
\hline & Male & 32.9 & 19.2 & 0.1 & 13.6 & 67.1 & & \\
\hline & Female & 44.8 & 17.4 & 13.1 & 14.3 & 55.2 & & \\
\hline Colom & & & & & & & & \\
\hline 1990 & Total & 45.7 & 24.1 & 2.0 & 19.5 & 54.3 & 9.6 & 44.7 \\
\hline & Male & 45.1 & 22.6 & 0.1 & 22.3 & 54.9 & & \\
\hline & Female & 46.6 & 26.3 & 5.0 & 15.2 & 53.4 & & \\
\hline 1998 & Total & 49.0 & 28.1 & 2.1 & 18.8 & 51.0 & 8.2 & 42.8 \\
\hline & Male & 49.2 & 28.4 & 0.2 & 20.7 & 50.8 & & \\
\hline & Female & 48.8 & 27.7 & 4.7 & 16.4 & 51.2 & & \\
\hline Costa & & & & & & & & \\
\hline 1990 & Total & 41.2 & 18.9 & 5.8 & 16.4 & 58.8 & 22.0 & 36.8 \\
\hline & Male & 37.7 & 19.1 & 0.3 & 18.3 & 62.3 & & \\
\hline & Female & 47.5 & 18.6 & 15.8 & 13.1 & 52.5 & & \\
\hline 1998 & Total & 45.4 & 17.5 & 6.0 & 21.9 & 54.6 & 17.0 & 37.6 \\
\hline & Male & 42.2 & 16.5 & 0.3 & 25.3 & 57.8 & & \\
\hline & Female & 50.7 & 19.0 & 15.4 & 16.2 & 49.3 & & \\
\hline Ecuad & & & & & & & & \\
\hline 1990 & Total & 55.6 & 35.4 & 5.0 & 15.3 & 44.4 & 18.7 & 25.7 \\
\hline & Male & 51.7 & 32.6 & 0.7 & 18.4 & 48.3 & & \\
\hline & Female & 62.1 & 39.9 & 12.1 & 10.1 & 37.9 & & \\
\hline 1998 & Total & 58.6 & 33.0 & 6.1 & 19.5 & 41.4 & 14.8 & 26.6 \\
\hline & Male & 54.5 & 28.9 & 1.0 & 24.6 & 45.5 & & \\
\hline & Female & 64.1 & 46.7 & 9.4 & 8.0 & 35.9 & & \\
\hline
\end{tabular}

(continued on next page) 
Table 3 (continued)

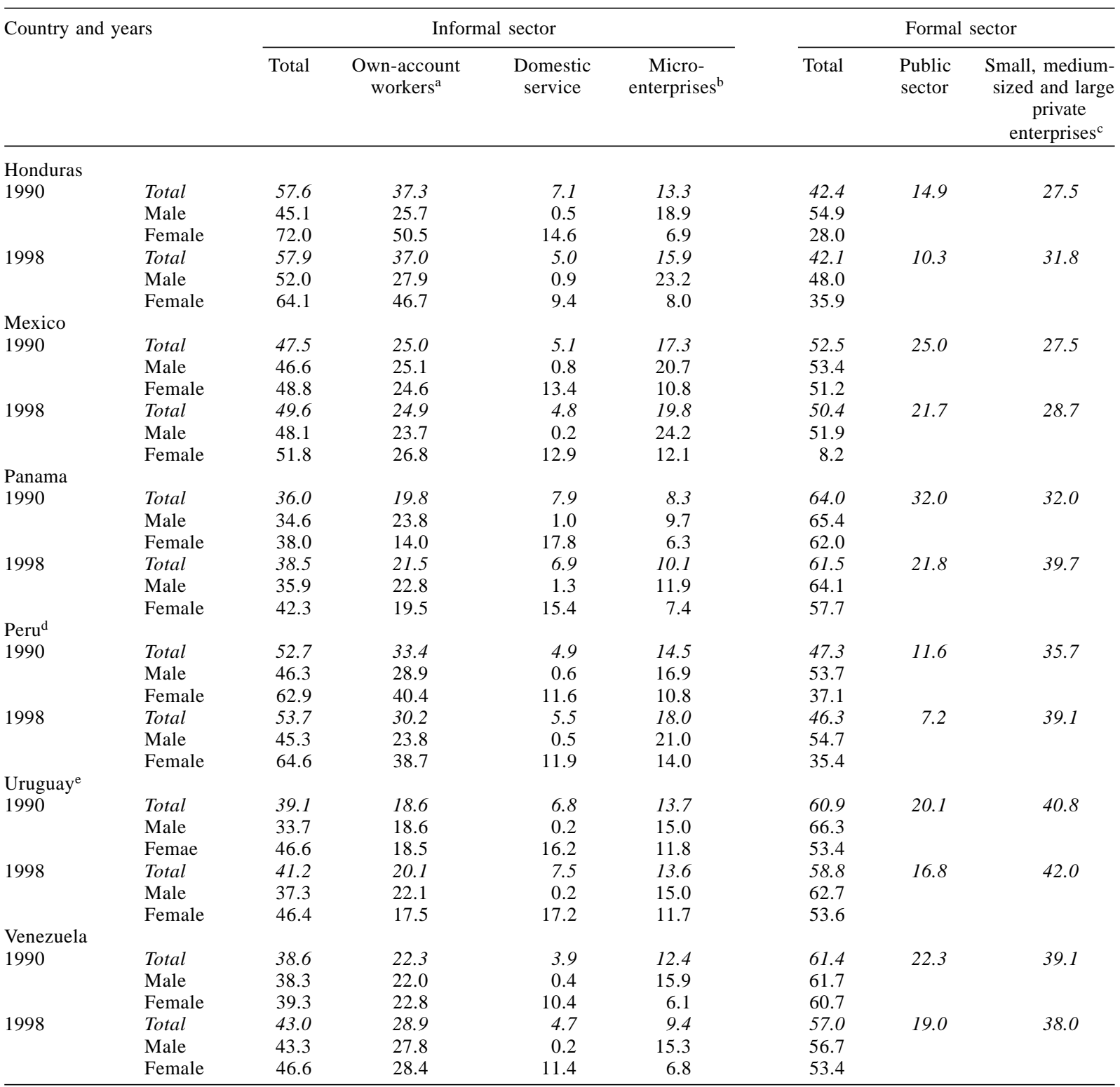

Source: ILO estimates, based on country household surveys and other official sources (revised series).

a Includes own-account workers (other than professional and technical workers) and unpaid family workers.

${ }^{\mathrm{b}}$ Employed in establishments of up to five workers.

c Enterprises with six or more workers.

d Metropolitan Lima.

e Montevideo.

the situation in Latin America in the recent past. Nine out of every ten new jobs created in the 1990s were in services, but $70 \%$ of these were in low-productivity services, chiefly personal, retail trade and transportation services in the informal sector. Under these circumstances, the shift to services means a decline in employment quality.
The third major change in the employment structure in the 1990s was the shift from formal to informal employment. As was mentioned earlier, the limited job creation capacity of the formal economy, both public and private, left increasing numbers of people with no alternative but to find or create their own occupations in the informal sector; in the absence of insurance, un- 
FIGURE 1

Latin America (selected countries): Employment trends in the 1990s

(Share in employment growth)

Towards the tertiary sector

From goods to services

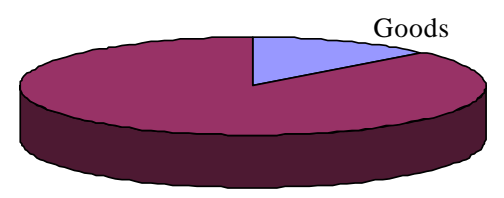

Services

Growth of informal services

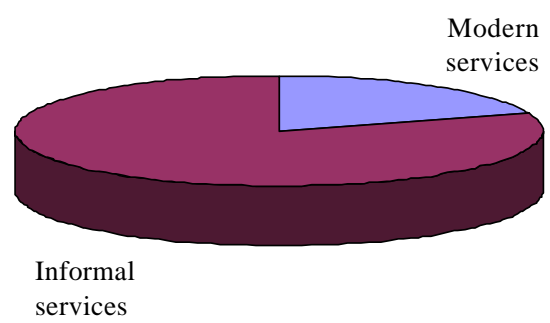

Towards the informal sector

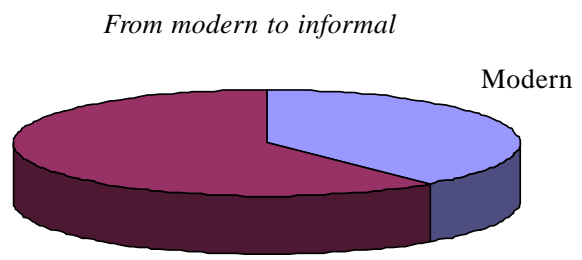

Informal

Modernization of the informal sector

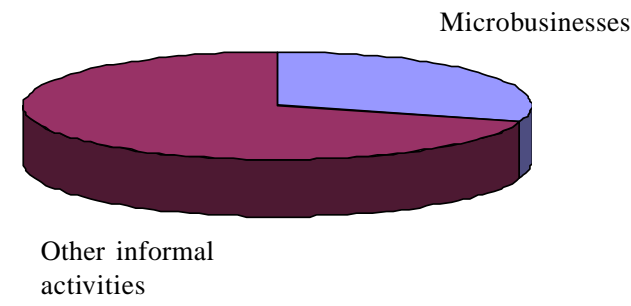

employment is a luxury that very few can afford. Slow and erratic growth, and the shedding of labour by the public sector during adjustment, conspired against the creation of jobs in modern activities.

As a result, the proportion of the workforce in informal employment expanded from $44 \%$ to $48 \%$ between 1990 and 1998. This includes own-account work, unpaid work in family businesses, domestic service and microenterprise (less than 5 employees). Only in Argentina, Chile and Honduras did informal employment not expand as a share of the total, while in the remaining countries informal employment grew twice as fast as total non-agricultural employment.

In the region as a whole, 61 out of every 100 jobs created in the 1990s were informal. As was mentioned earlier, the great majority of new jobs in services were informal; furthermore, the most dynamic component of informal employment growth has been work in microenterprises. Of every 10 new informal jobs, more than three were contributed by microenterprises (figure 1). This could suggest a positive change within informal employment, since microenterprises are more highly organized than most informal activities and average incomes from microenterprises are higher than those of the rest of the informal sector, although not as high as those of the formal sector. Average incomes in microenterprises are about $90 \%$ of average incomes in modern activities generally, but only $55 \%$ of average incomes in medium-sized and large enterprises.

Nevertheless, microenterprises are increasingly offering valid employment options. In 1998, for instance, they accounted for all new jobs created. Further analysis is needed, however, since although incomes are better, working conditions, job stability and social protection are far from being acceptable. Between $65 \%$ and $95 \%$ of those working in microenterprises do not have a written contract, and between $65 \%$ and $80 \%$ are not covered for health risks or old age. They tend to work longer hours and are more likely to have accidents at work. Breaches of basic labour rights (child labour, freedom of association, collective bargaining and forced labour) are also more frequent in establishments of this size than in larger ones. Of course, insecurity is not solely a characteristic of small enterprises; it is also to be found in medium-sized and large firms (ILO, 1998).

The fourth process identified is the loss of job security resulting from increased competition in a more flexible labour environment. The search for cost reductions and flexibility to allow for improvements in competitiveness has led to labour law reforms introducing flexibility at the margins. For new jobs, "non-standard" contracts have been introduced as a less costly and more 
flexible alternative to the open-ended contracts that were once the norm. The resultant increase in flexibility and reduction in labour costs were expected to lead to growth in the number of waged jobs created.

In the 1990s waged employment did indeed increase more rapidly than total employment, suggesting that the reform produced incentives to hiring. However, the social cost involved was increasing insecurity of employment. The introduction of "non-standard" labour contracts was accompanied by an increase in the number of workers without any written employment contract at all. It should be noted that neither nonstandard contracts nor the lack of any written legal contract automatically entail lower labour protection than standard contracts. Only the reform in Argentina made allowance for this reduction in temporary contracts, the existence of an employment relationship being subject to proof in the absence of a written contract. However, inspection and control become more difficult with temporary contracts. In the case of workers without contracts, many are unofficial and work for cash, so that their conditions of employment are almost impossible to check. This development, furthermore, has come about in a situation where labour inspection is generally weak, and because it is rigid contracts that are legally recognized as standard ones, the reform has meant that powers of guidance have been diminished.

In 1996, workers without contracts or with "nonstandard" contracts accounted for $30 \%$ of all workers in Chile, $40 \%$ in Argentina and Colombia and $74 \%$ in Peru. Most worked in microenterprises: $50 \%$ in Chile, $65-70 \%$ in Argentina and Colombia and $80 \%$ in Peru. However, medium-sized and large enterprises recorded the largest proportion of "non-standard" contracts and significant percentages of workers without contracts: $6 \%$ in Chile, $11 \%$ in Peru and $32 \%$ in Argentina and Colombia. In the case of microenterprises, informal working and lack of employment security have a clear tendency to overlap, since both are mainly the result of inability to pay the costs of labour protection. With larger enterprises, the number of unregistered workers is an indication that the law is being circumvented (Tokman and Martínez, eds., 1999).

Not only is the proportion of workers potentially or actually exposed to insecure employment conditions high, but in most countries insecure employment accounts for all job growth in the 1990s. Of the four countries analysed, only in Colombia was there an increase in open-ended employment; in Argentina, Chile and Peru there was a fall in the absolute numbers of such contracts. The exact nature of the transition from per- manent to temporary employment differed from country to country. In Argentina, the decline in the number of open-ended contracts was entirely offset by growth in the number of workers without contracts, mainly in larger enterprises. In Peru, the decline in open-ended employment was compensated for in equal proportions by workers with temporary contracts and workers without contracts, mostly in microenterprises. In Chile, most new jobs were provided by larger enterprises under temporary contracts.

The four processes described resulted in a decline in the quality of labour protection in the 1990s. Privatization, which could have been a positive development, was not so because of the inadequacy of job creation in modern private-sector companies. A shift towards tertiary employment is also a priori neutral, since good jobs in services could make up for a decline in available manufacturing employment. However, most of the new jobs in services were of low productivity. Increased informal working and insecure employment conditions clearly resulted in lower job quality, although this was somewhat offset by the rapid expansion of employment in microenterprises.

The changes in the employment structure can be more clearly identified if looked at from a longer-term perspective. As can be seen in figure $2,{ }^{2}$ during the three decades prior to adjustment (1950-1980) an average of

FIGURE 2

Latin America (selected countries): Sectoral contribution to job creation, 1950-1996

(Number of jobs contributed out of every 10 new jobs)

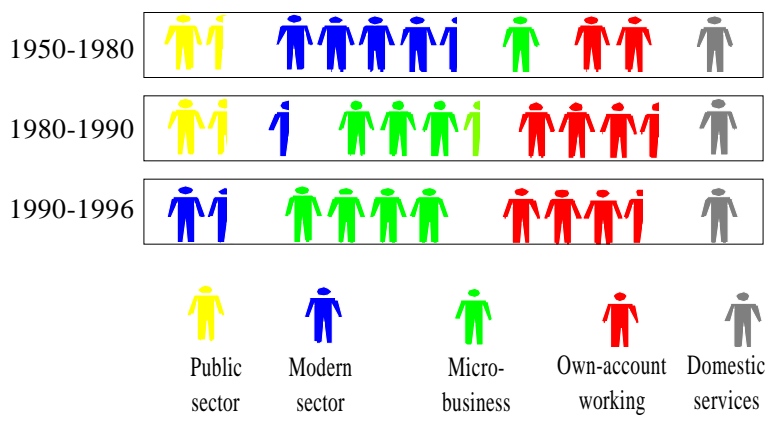

\footnotetext{
2 Owing to the nature of the available data, in the case of some countries the informal sector as defined for the purposes of figure 2 includes microbusinesses with up to 10 employees, and its employment share relates to urban employment. The revised series, in which the informal sector includes microbusinesses with up to five employees and is related to urban employment, does not permit of long-term comparison.
} 
$60 \%$ of new jobs in Latin America were created by the formal sectors of the economy, with government accounting for $15 \%$ and medium-sized and large privatesector companies for $45 \%$. The informal sector contributed $40 \%$ of new jobs, of which only $10 \%$ were in microenterprises (ILO, 1996).

A substantial change in the employment structure occurred during the adjustment decade of the 1980s. The contribution made by employment in modern industries fell to two out of every ten new jobs, this decline being most pronounced in modern private-sector companies that had to adjust to a more open economy. The informal sector acted as a buffer: it doubled its contribution to job creation, mostly in microenterprises, where it more than tripled. The 1990s saw a recovery in labour absorption in larger private-sector companies and continuing growth in informal employment.

To sum up, privatization has meant that publicsector employment is no longer contributing to labour absorption. Larger enterprises, while they have been recovering from the adjustment decade, are still well below the pre-adjustment level, and technological change and decentralization of production and employment mean that they are unlikely to be able to return to it. Indeed, business of all sizes account for the same 5.5 out of every 10 new jobs as they did in the preadjustment period. The difference is that the main contributors now are microenterprises (including small enterprises). This being the case, and informal and insecure employment still being the norm in the sector, this employment shift has led to a decline in job quality.

\section{d) Wage trends and differentials}

The adjustment process was expected to have two effects on wages. It was predicted that wage levels would increase as productivity grew, while wage differentials by skill level would narrow as the demand for unskilled labour increased because of the expansion of trade based on labour-intensive sectors.

In 1990, both industrial and minimum wage levels were lower in real terms than they had been in 1980. In both cases, though, there was a recovery during the 1990s. This was mainly due to success in reducing inflation, which declined from three digits to less than $10 \%$ on average across Latin America. Latterly, productivity growth also contributed, particularly in the industrial sector. Nonetheless, as table 2 shows, minimum wages are still substantially lower than in 1980 .
Wage differentials have behaved in an unexpected manner, with the gaps between minimum and industrial wages and differences by skill or educational level tending to widen. Industrial wages grew by $1.4 \%$ a year between 1990 and 1997, while minimum wages increased by only $0.3 \%$. Across Latin America, income differentials between professional and technical workers and those employed in low-productivity sectors increased from $40 \%$ to $60 \%$ on average between 1990 and 1994. This was the result of substantial growth in the real incomes of high-skilled workers in modern activities and slow increases or even declines in the wages of unskilled labour in low-productivity sectors. In eight out of ten countries for which data were available, the wage gap by skill level widened (ECLAC, 1997a). The same can also be seen when the wages of skilled workers are compared with those of blue-collar workers since 1988 (IDB, 1998).

As wage gaps in Latin America widened over this period, exactly the opposite trend was being seen in the South-East Asian countries, despite the fact that in 1980 wage gaps in Latin America were already the largest in the world. By 1997, the wage gap in Latin America was 1.9 times as high as in developed countries and the South-East Asian countries.

A number of explanations can be put forward for this unexpected development. The effect of capital liberalization on the prices of capital goods could have brought about an increase in investment and a concomitant demand for skilled labour. The expansion of imports from countries like China with an even greater abundance of unskilled labour than Latin America, and currency appreciation, which favoured growth in more skill-intensive non-tradable goods, are other factors (Lustig, 1998).

In addition, studies done on Brazil, Chile and Peru (Meller and Tokman, 1996; Paes de Barros and others, 1996 and Saavedra, 1996) suggest that the maturity and characteristics of the trade liberalization process influence the evolution of wage differentials. In Chile, where the liberalization process was at a more mature stage, large enterprises were able to expand employment after 1984; in Brazil and Peru (two late starters in the process), large enterprises reduced employment in order to raise productivity and competitiveness, while most labour absorption took place in small enterprises and microenterprises. In Chile demand for skilled labour grew, while in the other two countries there was a shift of labour from higher- to lower-productivity enterprises and sectors, a process that was accompanied by net employment growth in Peru but a net contraction in Brazil. 
Argentina, Chile, Colombia and Peru: Insecure employment

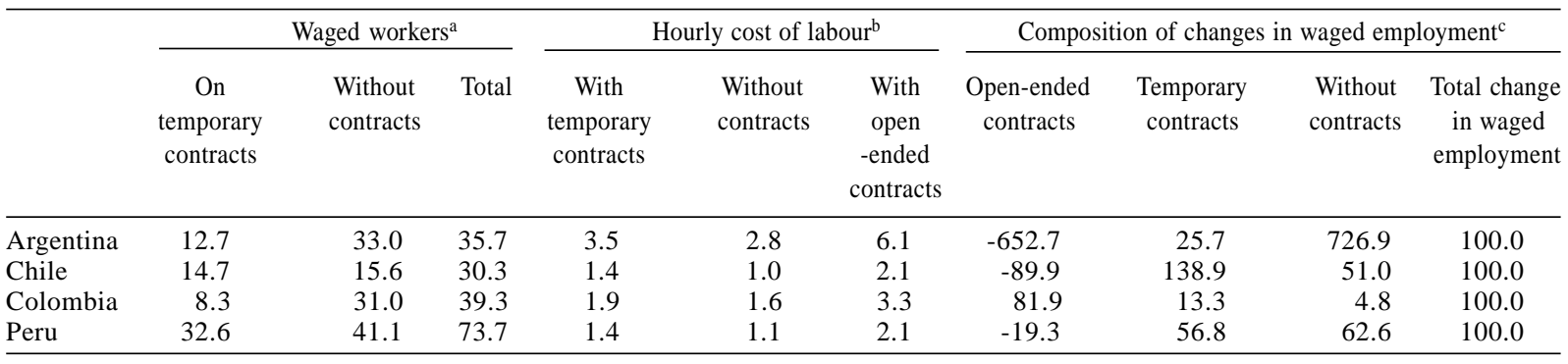

Source: Tokman and Martínez (eds.) (1999) and ILO (1998).

a As percentages of total waged employment.

b In dollars.

c As percentages of changes in waged employment between 1990 and 1996.

In both cases, however, wages for unskilled labour declined, either as a result of this employment shift or because of the introduction of lower levels of labour protection. Workers in microenterprises earn an average of $30 \%$ to $50 \%$ less than those in larger establishments (ILO, 1997a), and the figure is still $20 \%$ even when personal characteristics are homogenized (IDB, 1998). However, large companies replacing workers on longterm contracts with temporary ones reduce wages by between $35 \%$ and $40 \%$, and by an additional $15 \%$ to $30 \%$ if no written contract is drawn up (table 4). It is mainly unskilled workers who are switched to employment contracts of this type, and this practice has neutralized any demand effect that may have resulted from trade liberalization (ILO, 1998).

\section{e) Poverty and equity}

Poverty and inequality have increased during the reform process. Today, on average, there are more poor people and income differences are larger in Latin America than before. The trend has not been a continuous one. During the 1990s, when several countries had already completed the stabilization and trade liberalization phases, poverty fell in most of the countries for which data are available. Only in Argentina and Venezuela did the level of poverty rise, while in Mexico it remained constant. In the 13 remaining countries for which there are data, reported poverty fell (ECLAC, 1999).

The level of poverty is still higher today than in 1980, and there has been no improvement in equity. On the contrary, income concentration has increased substantially since the early 1980 s, so that the Gini coefficient is now at a level similar to that seen in 1970 (0.52). This is because the income share of the poorest quintile has declined while that of the highest quintile has risen continuously, a rise that was interrupted only between 1980 and 1983 . The intermediate quintiles, while performing better than the poorest, have still not recovered the income shares they had at the beginning of the 1980s. In fact, of the two countries (Chile and Uruguay) that can show a significant decrease in poverty, only in Uruguay has equity increased at the same time.

Income concentration in Latin America has historically been the highest in the world. At present, the income share of the top $5 \%$ is double that of the same group in industrialized countries, and more than $60 \%$ higher than in South-East Asian countries. At the other extreme, the income share of the poorest $30 \%$, at $7.5 \%$, is the lowest in the world, being just $60 \%$ of the equivalent level in industrialized and Asian countries (IDB, 1998). When a successful performer like Chile is compared to the United States, it is found that the income shares of the bottom $20 \%$ are similar (about $4.5 \%$ ). However, to find a time when the shares of the upper $20 \%$ were comparable, we have to go back as far as 1929. If the Gini coefficient is calculated for $90 \%$ of the Latin American population (excluding the upper $10 \%$ ) it is found to average 0.36 , which is similar to the level seen in the United States, while in six of the countries it is actually lower than in the United States (IDB, 1998). This clearly shows that greater income concentration among the highest groups is a key explanatory factor.

Of no less importance is the question of why globalization, and the adjustment package that accompanied it, did not help to bring Latin American equity levels closer to those of the rest of the world. Conventional wisdom, based on the pioneering studies of Kuznets, would lead one to expect that, after a period 
of increased income concentration in the early stage of development, equity would improve. This conventional wisdom does not seem to hold today, even for developed countries. The trend towards greater equity has been cut short or, at best, suspended. Inequality has increased in the United States since the end of the 1960s, while in the United Kingdom it increased from 1979 to 1989, and it likewise rose in Sweden after 1988 (Atkinson, 1996 and Krugman, 1995). This suggests that Latin American countries may be following a universal path as a result of policy homogenization, without having passed through the stage of increased equity seen earlier in those countries.

Several factors can help explain why globalization has not improved equity in Latin America. They relate to population dynamics, the distribution of opportunities and the workings of labour markets during the adjustment process.

Rapid population growth has resulted, particularly in poor households, in larger household size (50\% more members in the lowest quintile than in the highest), higher dependency rates (almost treble) and lower participation rates (60\%) (ECLAC, 1997a).

Access to opportunities, and particularly to education, is also unequal. Although the time people spend in education has increased on average (albeit more slowly than in South-East Asian countries), it tends to be unequally distributed. There is a high drop-out rate among poor households. While $94 \%$ of poor chil- dren in educationally advanced countries are enrolled in the first year of school, the figure is only $76 \%$ in the less advanced countries. Enrolment rates decrease to $63 \%$ and $32 \%$ by the fifth year, and to $15 \%$ and $6 \%$ by the ninth year. Entry rates are similar for poor children and children from higher-income families, but the latter remain at school for longer periods. By the fifth year, the rates are $93 \%$ and $83 \%$, while by the ninth year they are 58\% and 49\% (IDB, 1998). Inequality of access is reinforced by higher rates of education to university level among higher-income families and by differences in education quality. Academic attainments (in mathematics and science) are on average 50\% higher in private schools, which are attended only by children from higher-income families, than in State schools, which $90 \%$ of the children of the poor attend.

A significant proportion of income differences, more than $55 \%$, is explained by labour market outcomes. As argued above, increased unemployment, employment shifts towards less productive, more unstable jobs and increased wage differentials tend to widen income inequalities since they affect poor households disproportionately. Unemployment rates are higher in poor households (in Chile the rate for the poorest quintile was 2.7 times that for the richest quintile in 1996). In addition, job allocation is segmented. High-quality, well-paid jobs are largely held by members of higher-income families, while low-qualTABLE 5

Latin America (nine countries): Indicators of employment transformation, informal working and average income growth by income group ${ }^{a}$

(Percentages and annual growth rates)

\begin{tabular}{|c|c|c|c|c|c|c|c|c|c|c|c|c|c|}
\hline \multirow[t]{2}{*}{ Country } & \multirow[t]{2}{*}{ Period } & \multicolumn{4}{|c|}{ Employment $^{\mathrm{b}}$} & \multicolumn{4}{|c|}{ Informal working ${ }^{\mathrm{c}}$} & \multicolumn{4}{|c|}{$\begin{array}{l}\text { Average income } \\
\text { of the employed }\end{array}$} \\
\hline & & Total & Low & Medium & High & Total & Low & Medium & High & Total & Low & Medium & High \\
\hline Argentina & (1990-96) & 0.5 & 1.0 & 1.2 & -1.3 & 66 & 79 & 77 & $\ldots$ & 4.5 & 3.5 & 4.2 & 6.4 \\
\hline Brazil & $(1992-95)$ & 3.5 & 5.8 & 2.2 & 3.5 & 81 & 66 & 85 & 95 & 1.3 & 1.3 & 1.2 & 1.5 \\
\hline Chile & $(1990-96)$ & 3.1 & 3.8 & 2.7 & 2.9 & 29 & 14 & 30 & 42 & 5.6 & 4.1 & 5.8 & 5.9 \\
\hline Colombia & $(1992-96)$ & 1.8 & 1.2 & 1.9 & 2.6 & 37 & $\ldots$ & 66 & 22 & 3.6 & 2.5 & 3.3 & 3.9 \\
\hline Costa Rica & (1990-95) & 4.4 & 3.7 & 3.5 & 7.0 & 51 & 70 & 48 & 42 & 1.9 & -0.6 & 1.4 & 2.7 \\
\hline Mexico & $(1990-95)$ & 6.4 & 7.8 & 6.0 & 5.5 & 58 & 87 & 54 & 18 & -2.1 & -3.8 & -2.1 & 0.2 \\
\hline Panama & $(1989-95)$ & 6.8 & 6.3 & 7.2 & 6.8 & 38 & 45 & 35 & 31 & 1.4 & 2.6 & 0.6 & 2.2 \\
\hline Peru & $(1991-95)$ & 5.1 & 6.3 & 4.2 & 5.4 & 69 & 97 & 51 & 32 & 3.0 & 2.7 & -0.2 & 3.0 \\
\hline Venezuela & $(1990-96)$ & 2.6 & 2.3 & 2.2 & 3.8 & 77 & 100 & 87 & 31 & -10.3 & -11.5 & -9.8 & -9.1 \\
\hline
\end{tabular}

Source: ILO, on the basis of household surveys in Argentina (Greater Buenos Aires), Brazil (urban area), Chile (urban area), Colombia (10 metropolitan areas), Costa Rica (urban area), Mexico (39 cities), Panama (metropolitan area), Peru (metropolitan Lima) and Venezuela (urban area).

a Data refer to those employed in urban areas, excluding the agricultural and mining sectors. Workers have been grouped according to income levels as determined by per capita household income quintiles. The income levels are: low (quintile I + quintile II), medium (quintile III + quintile IV) and high (quintile V). All indicators relate to the period shown for each country.

b Annual rate of employment growth (average for the period shown for each country).

c Percentage of new jobs in informal activities during the period shown for each country.

d Annual rate of average income growth for those in work, measured in constant prices (average for the period shown for each country). 
ity, informal and unskilled jobs tend to be taken up by people from poor households. Employment among the poorest 40\% in Chile increased between 1992 and 1994; while formal employment declined, the number of informal jobs grew by more than $20 \%$. The opposite happened in the upper quintile, where formal employment expanded by $13.5 \%$ and informal employment decreased by $2.7 \%$. More than half of all new jobs requiring high educational levels went to upper-income families, while upward mobility among the bottom $40 \%$ was limited, as they tended to take up jobs with secondary or technical requirements (Tokman, 1998).
Labour market outcomes are a key factor in the development of poverty and equity. This does not mean that non-work incomes are not important, but that the two cannot be considered in isolation from one another. Income concentration by household is currently similar to the concentration of earnings by worker in 14 Latin American countries (with Gini coefficients of 0.52 and 0.51 respectively) (IDB, 1998). The above analysis, then, can be translated into poverty and equity, and we have done this for nine countries in the 1990s (tables 5 and 6). The countries included were Argentina, Brazil, Chile, Colombia, Costa Rica, Mexico, Panama, Peru and Venezuela (ILO, 1997a).

\begin{tabular}{|c|c|c|c|c|c|}
\hline \multicolumn{6}{|c|}{ TABLE 6} \\
\hline \multirow{2}{*}{ Country } & & \multicolumn{3}{|c|}{ Levels } & \multirow{2}{*}{ Inequality ratio $^{b}$} \\
\hline & & Low & Medium & High & \\
\hline \multicolumn{6}{|l|}{ Argentina } \\
\hline & 1990 & 7.9 & 34.6 & 57.5 & 7.0 \\
\hline & 1996 & 6.8 & 35.4 & 57.8 & 8.0 \\
\hline & Change & -1.1 & 0.8 & 0.3 & \\
\hline \multicolumn{6}{|l|}{ Brazil } \\
\hline & 1992 & 5.1 & 29.2 & 65.7 & 19.2 \\
\hline & 1995 & 5.3 & 27.3 & 67.4 & 21.5 \\
\hline \multirow{2}{*}{\multicolumn{6}{|c|}{ Chile }} \\
\hline & & & & & \\
\hline & 1990 & 11.3 & 30.7 & 58.0 & 9.4 \\
\hline & 1996 & 10.8 & 30.6 & 58.6 & 10.4 \\
\hline & Change & -0.5 & -0.1 & 0.6 & \\
\hline \multicolumn{6}{|l|}{ Colombia } \\
\hline & 1992 & 16.8 & 33.5 & 49.7 & 4.3 \\
\hline & 1996 & 15.6 & 33.0 & 51.4 & 4.6 \\
\hline \multirow{2}{*}{\multicolumn{6}{|c|}{ Costa Rica }} \\
\hline & & & & & \\
\hline & 1990 & 19.2 & 41.6 & 39.2 & 3.0 \\
\hline & 1995 & 15.8 & 38.7 & 45.5 & 3.4 \\
\hline & Change & -3.4 & -2.9 & 6.3 & \\
\hline \multicolumn{6}{|l|}{ Mexico } \\
\hline & 1990 & 15.0 & 37.5 & 47.5 & 6.0 \\
\hline & 1995 & 14.3 & 35.9 & 49.8 & 7.1 \\
\hline & Change & -0.7 & -1.6 & 2.3 & \\
\hline \multicolumn{6}{|l|}{ Panama } \\
\hline & 1989 & 14.3 & 37.7 & 48.0 & 4.7 \\
\hline & 1995 & 14.7 & 35.9 & 49.4 & 4.7 \\
\hline & Change & 0.4 & -1.8 & 1.4 & \\
\hline \multicolumn{6}{|l|}{ Peru } \\
\hline & 1991 & 13.2 & 34.7 & 52.1 & 7.9 \\
\hline & 1995 & 14.2 & 30.9 & 54.9 & 8.5 \\
\hline \multirow{2}{*}{\multicolumn{6}{|c|}{ Venezuela }} \\
\hline & & & & & \\
\hline & 1990 & 18.4 & 38.5 & 43.1 & 4.7 \\
\hline & 1996 & 13.6 & 39.0 & 47.4 & 7.6 \\
\hline & Change & -4.8 & 0.5 & 4.3 & \\
\hline
\end{tabular}

Source: ILO, on the basis of household surveys in Argentina (Greater Buenos Aires), Brazil (urban area), Chile (urban area), Colombia (10 metropolitan areas), Costa Rica (urban area), Mexico (39 cities), Panama (metropolitan area), Peru (metropolitan Lima) and Venezuela (urban area).

a Constant prices.

b The inequality ratio measures the relationship between the nominal average incomes of the highest level (quintile V) and the lowest level (quintiles I and II). 
On average, in the nine countries included, both employment and income per worker increased in the 1990s, but the distribution of income favoured the upper $20 \%$ of families. Employment grew fastest in poor households, followed by households in the upper $20 \%$ of income. Middle-income groups benefited the least (figure 3). Average income, however, grew most rapidly in the higher income group, less rapidly in the middle and most slowly among poor households. This is a consequence of segmented access to jobs by different income groups. The poor, lacking in human capital, tend to get access to informal jobs, while higherincome families tend to take up better jobs. About 70 out of every 100 new jobs taken up by the poorest $40 \%$ were informal, while in the case of the middle $40 \%$ the ratio was 52 out of every 100 new jobs. As a result, income concentration, as measured by the income difference between the top $20 \%$ and the bottom $40 \%$, increased in all the countries considered. Both the poor and the intermediate groups saw their share of total income diminish, the upper $20 \%$ being the only gainers. It seems likely, however, that relative poverty decreased. Growth in employment and in earnings per worker, plus an increase in the number of family members at work, resulted in higher incomes for the poor and lower poverty in most countries during this period, the exceptions being Mexico and Venezuela.

The situation is fairly homogeneous across all the countries. Incomes per worker grew fastest in the upper-income group in all the nine countries considered, and employment did so in six of them. The situation as regards developments in the poor and middle groups is more diverse. In most countries, employment grew more rapidly for the poorest $40 \%$ than for the middle $40 \%$. However, income per worker grew faster for the middle-income group than for the low-income group in six of the nine countries studied. As noted earlier, this was the result of differentiated access to jobs. Income differentials between the top $20 \%$ and the bottom $40 \%$ increased in all cases, with the cost being borne by the poor and middle groups. In half the countries the poor lost more ground than the middle group, while in the remainder the reverse was true.
FIGURE 3

Latin America (selected countries): Employment and income growth by income level, 1990-1996

(Percentages)

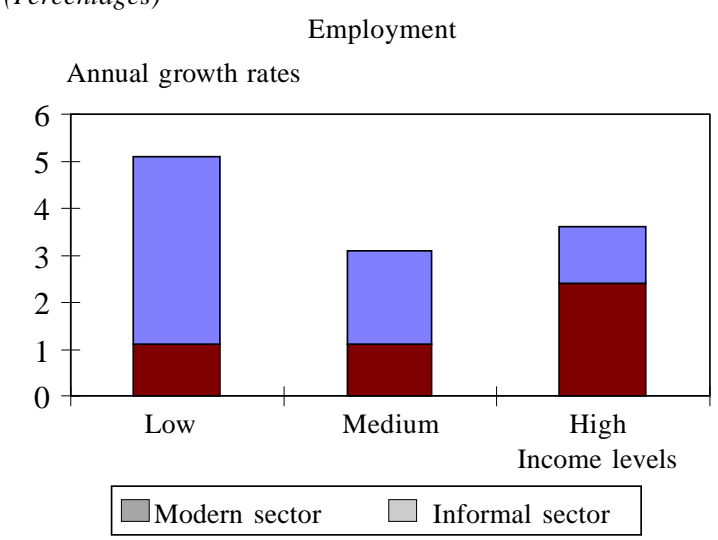

Average real income

Annual growth rates

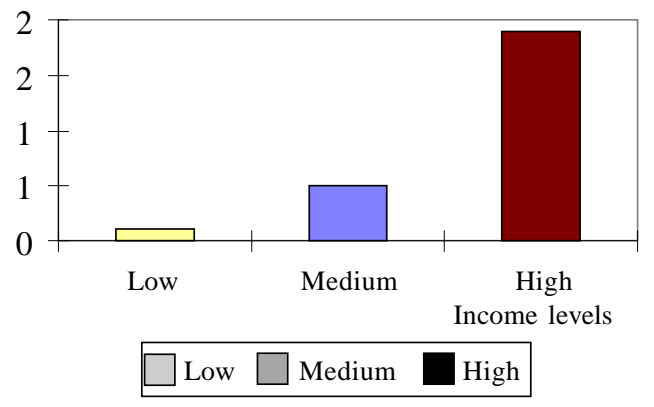

Income distribution among those in work

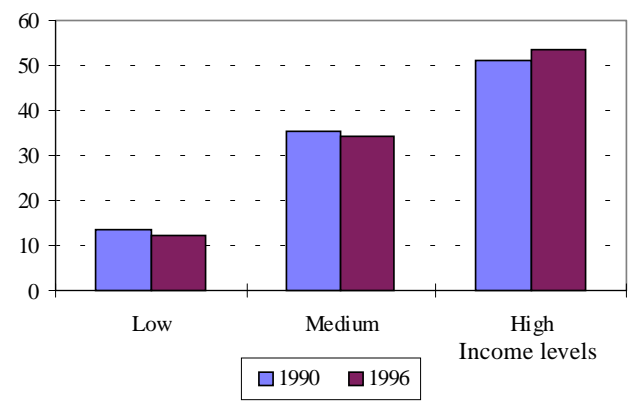


III

\section{Adjustment, global economies and social stratification}

Both the adjustment process in national economies and the subsequent integration of these into the international economy have had a significant impact on the social stratification system. This is because that system is mainly based on an occupational structure that has changed to reflect the transformations wrought in the labour market by economic restructuring. Some of the changes that have taken place, and the sociological consequences of these, will be analysed below, with particular attention being paid to four aspects. The first is the relationship between the transformation of public employment and middle class impoverishment. The second is the way privatization generates increased social heterogeneity, as a result of both involuntary labour mobility and the growth of outsourcing. The third is the influence of transnationalization on labour relation systems. Lastly, we shall look at the increased differentiation emerging in employment growth areas, like microenterprise and agriculture.

\section{Public-sector employment and the middle class}

The first important issue is the new role of the State and its impact on the labour market. This transformation has had two main effects. In the first instance, publicsector employment has declined in virtually all the countries of the region. On average, public-sector employment has decreased from $16 \%$ of the economically active population at the beginning of the 1980 s to $13 \%$ today, a fall of almost $20 \%$. This average masks particularly steep drops in some countries. For example, between 1990 and 1997 public-sector employment decreased by $32 \%$ in Argentina, 33\% in Bolivia, 22\% in Costa Rica and $28 \%$ in Panama. This process has had a large influence on social stratification in Latin America. It is a well documented fact that the origins and development of the middle class in Latin America were closely associated with the role of the State in promoting social and economic development during this century. In some countries this process began in the early decades of the century, in others it took place after the Second World War, and in others again it is still going on, but it is a feature of the entire region. This role encompassed the creation of public employment and the hiring of administrative staff to implement the development policies of the State, including health, education, public works and housing. The State was involved in creating employment in public enterprises of all kinds, but essentially in those sectors deemed to be of national strategic importance (utilities, key natural resources and basic industries). One illustration of the importance of public-sector employment to the development of the middle class is the observation (Echeverría, 1985) that, in the 1970 s, $60 \%$ of all Latin American professionals were civil servants.

The occupational status of civil servants who have lost their jobs as a result of the decline in public-sector employment is unclear, and probably varies between and within countries. In some instances former civil servants have been eligible to receive compensation payments, with which they have been able to start their own businesses, usually as independent contractors or as micro-entrepreneurs. In many of these cases their position may have improved. In other cases, these redundancies have led to downward mobility. The fact is that, in some countries, people discharged from the civil service and public-sector enterprises have experienced impoverishment and loss of status, especially those who were not professionals and whose status was based not on their educational attainments but on the occupational positions they held.

Again, those who have remained in public employment have also lost status. With the economic adjustment measures that have been taken, the importance of State administration has been reduced. At the same time, the prevailing ideological standpoint plays down the role of the State in society, and public functions do not have the same prestige as before. One indication of this is the reduced remuneration now given to civil servants; during the 1980s, the salaries of public employees fell by an average of $30 \%$ (ILO, 1992).

Of course, civil servants still enjoy considerable employment stability, coupled with a certain amount of social protection and safety nets that, even though they are far from satisfactory, provide some security 
from the most pronounced of the negative trends operating in today's labour market. Furthermore, not all the remaining civil servants have seen their position worsen. One group, albeit small, have improved their incomes and status because they have been given increased responsibilities and because demand from the private sector for their type of specialization is high. This is particularly true of those working for essential institutions in the new economic system, such as those in charge of overseeing and collecting tax revenues or customs duties. It is also true of those with a regulatory role in different areas of the financial system such as banking, insurance and stock markets, and in the institutions created to regulate privatized social security activities and utilities. As a result, wage and status differentials have widened in what used to be a very homogeneous sector. The increasingly heterogeneous character of the sector is not necessarily a negative feature. Indeed, it may lead to greater economic efficiency in the public sector if incentives related to labour productivity are introduced, as in fact is happening in areas like education and health. Furthermore, if a highly skilled labour force can be retained in the civil service by keeping wages and working conditions competitive with the private sector, then the quality of the product will improve. Creating opportunities for social mobility and higher status for some of those working in the public sector by allowing wage differentials to increase can result in improvements to the overall performance of the sector.

\section{Social heterogeneity and privatization of public enterprises}

The second feature of the changed role of the State is the privatization of public-sector enterprises that has taken place throughout Latin America. Privatization has had a major impact on the way the labour market works, particularly where certain of its institutional characteristics are concerned. Labour market flexibility has been achieved by various means. The first is greater scope to dismiss workers. In almost all public enterprises that have been privatized, a proportion of the labour force has been made redundant, the result in the first instance being an increase in open unemployment. This process, of course, is similar to the one seen in the private sector. Some of these workers have not been able to find stable work and have become downwardly mobile, alternating between periods of underemployment and unemployment. Others have found employment similar to the work they did for the public-sector enterprises concerned. Lastly, the rest have turned themselves into entrepreneurs, creating businesses of their own that in many cases have functional links to the large companies they were formerly employed by. In other words, when workers and employees in general are dismissed from newly privatized enterprises, some of their former functions, including some essential ones, are outsourced, and these enterprises subcontract with smaller firms for this work. In this way, a subcontracting chain is established. This arrangement has traditionally been quite common in some economic sectors, construction being an example. Today, it is also to be found in the primary sectors, basic utilities, telecommunications, commerce and financial services.

Outsourcing gives companies greater flexibility, enabling them to respond appropriately to fluctuations in the economic environment. Although there has been no thorough macro-evaluation in respect of income and employment, national case studies show that the impact is heterogeneous. For example, in the Chilean State mining sector, where extensive redundancies have been made to reduce production costs, many workers have been rehired on a subcontracting basis. While they have indeed forfeited employment stability and significant non-wage benefits, working conditions and accident rates have improved (ILO, 1997b). On the other hand, in many other cases income and employment conditions have deteriorated. Insecure employment abounds in different sectors and countries where subcontracting is becoming a common feature of the labour market. In these cases, temporary jobs, lack of social security coverage and the absence of unions, collective bargaining and training mechanisms may well be the norm, even though wages might be higher.

\section{Transnational enterprises and their social effects}

Privatization of State enterprises has also increased the presence of transnational corporations. This has generated a new managerial stratum, characterized by very high incomes, an international outlook (as opposed to national interests) and a corporate ideology based on the idea that globalization redefines national boundaries and local interests. This stratum is to be found not only in privatized public enterprises but also in private companies, particularly those engaged in trading, financial services and industry. One of the effects of the transnational status and management style of these managers is that they tend to apply international standards to labour relations, without recognizing national 
and local characteristics. Often they are also shareholders in the company, which gives them a concrete stake in its interests. They are also involved, however, in making the whole economic system work at a macro level, insofar as events in the capital and financial markets directly affect their own overall incomes (in countries where privatized pension funds have been allowed to invest in shares, this is also the case for all workers and employees participating in the system).

One specific kind of transnational presence is the so-called maquila or inbond assembly system whereby certain parts of a company's production process are transferred to another country, this usually being justified in terms of lower labour costs as these have a large direct effect on total production costs (labour accounts for $54 \%$ of total costs in the typical Central American maquila or inbond assembly plant, where labour costs are 3.5 times lower than in the United States). In some areas of Latin America, this form of production is increasingly important. In Central America, plants of this type now account for 250,000 jobs $(400,000$ if the Dominican Republic is included), representing $30 \%$ of employment in the formal industrial sector, $20 \%$ of export value added and about $10 \%$ of industrial GNP (Gitli, 1997). Their impact, then, has been significant, and in some cases particularly disadvantaged groups in the labour market, mainly women, have benefited from the presence of these plants in their respective countries. This has become a means of increasing labour force participation among these groups, which constitute a social stratum that is clearly dependent on the transnational activities increasingly being undertaken by firms from the developed world as national economies globalize.

The same study shows, however, that labour standards and even human rights are not always respected. Sweatshops are widespread, even though there is increasing pressure for foreign firms to comply with minimum standards in their host countries. The question that remains to be answered is whether this is at all possible when low labour costs are the driving force behind the very existence of the inbond assembly industry.

\section{Microenterprises and the informal sector}

Microenterprises, many of them informal, have by and large been the main source of employment in Latin America during the last decade. The social effects of this trend have been important. To begin with, it has weakened the waged workforce that traditionally sus- tained the labour movement. Permanent blue-collar workers in medium-sized and large industrial companies have increasingly been outnumbered by wage earners in microenterprises. Others have been turned into independent contractors, mainly in the trade and services sectors.

The way microenterprises have developed has, in many cases, reflected their relationship with the international economy. While a large majority of microenterprises cater to national markets, a proportion are now linked through exports to the world economy. Some authors have argued that this "neo-informality" is a characteristic of today's labour markets, particularly when enterprises form part of subcontracting chains with the inbond assembly operations of foreign companies, and when they have found specific niches in particular external markets (Pérez-Sáinz, 1996). In none of them, though, is there a significant division between labour and capital.

At this point it is worth recalling that up until the 1970s the evolution of social stratification in Latin America was a relatively straightforward process in which the labour force clearly experienced structural social mobility. Indeed, research carried out by Germani, Stavenhagen and Medina Echeverría, among others, suggests there was a long-standing trend of upward mobility from low-productivity occupations to higher-productivity ones, interpreted as being chiefly a shift between sectors (from agriculture to manufacturing and services) and between occupational categories (from blue-collar to non-manual) (see Filgueira and Geneletti, 1981).

This seems no longer to be the case. The position of the present paper is that one of the results of adjustment policies and the globalization of national economies has been the emergence of heterogeneous characteristics within segments of the labour market, and this phenomenon is seen most clearly when the microenterprise sector is analysed. "Small scale" means many different things in both economic and social terms. Some microenterprises are highly capitalized, have links to dynamic markets, operate in leading sectors and employ increasingly highly qualified workforces, while others again are conventional in terms of capital and labour use. Hence, heterogeneity is increasing as a result of current economic developments: those employed in enterprises that are linked to the developed strata have benefited in terms of income and employment opportunities (although not necessarily as regards employment quality), while those who remain cut off from the main thrust of the economy 
have lagged behind. They continue to work in low-productivity occupations, with low skills and little job security.

\section{Sectoral analysis}

Heterogeneous trends in the labour market, and the social impact these give rise to, can also be observed at the sectoral level. Social strata will vary according to the way businesses are linked with the rest of the economy (national and international). The development of agriculture clearly illustrates this point. Those agroindustrial sectors that have grown on the basis of external markets require a type of labour force different to that employed in traditional agriculture, and have generated a new set of occupations. Firstly, they require a relatively well trained and highly skilled labour force. Secondly, the jobs they generate are mostly temporary. Thirdly, they have opened up new waged employment options for people who were previously unemployed and/or not economically active, particularly women,

\section{IV}

\section{Final remarks}

Globalization cannot be isolated from the other policies that have accompanied it over the last twenty years. They constitute a policy compact that it is very difficult, both analytically and in practice, to break down into its constituent parts. Three processes have been scrutinized: globalization, privatization and deregulation. The effects on social stratification, mainly through labour market outcomes, have been the focus of our analysis, because the occupational structure is the basis of the system of stratification.

The main conclusion is that the social structure in Latin America has been placed under tension during the reform period. This tension has affected social cohesion and introduced greater heterogeneity. As with all processes, there are winners and losers. The difference this time is that the changes are substantial and will have a structural effect on peoples, societies and nations not only today but into the future.

Change, particularly during the 1990s, has not all been for the worse. Poverty is on a declining trend, and the poor are better off in income terms. However, equity has deteriorated. The winners are a minority, while whose increased participation in the labour market has led to changes in the organization of the family and the distribution of roles within it. Lastly, most of these jobs are remunerated according to labour productivity. These characteristics contrast strongly with those of the traditional worker, the permanent, low-skilled male wage earner, employed in the cultivation of traditional crops and earning, if he is lucky, the minimum wage. Within a single occupational category, therefore, the jobs available have become more diverse in terms of the workforce required, the personal characteristics of this workforce, productivity standards and time spent in the labour market. To sum up, we can say that heterogeneity has been a traditional feature of agriculture, an example of this being the coexistence of plantations and a peasant economy. The difference today is that this heterogeneity is also to be found within occupational categories so that, for example, the characteristics of waged labour vary depending on whether or not the specific sector concerned is linked to the wider economic system. the rest, not only the poor but middle-income groups as well, increasingly lag behind in relative terms. The effects of the policy compact on employment and earnings, as well as on equality of opportunities, have proven to be an important determinant of this outcome. In a region where inequality is already the highest in the world, this is an unwelcome trend.

There seems to be enough evidence to sustain the proposition that the policy compact has led to greater concentration. Most of the positive effects have benefited sectors that were already situated in the upper echelons of income distribution: the policy compact has favoured the relatively rich. Those negative effects that have occurred in the labour market as a result of the policy compact -increasingly insecure working conditions (lack of contracts, social protection, etc.), the shift of employment towards the service sector and informal jobs, unemployment- have mostly been concentrated among sectors that were already relatively poor. Thus, differences have increased. Wage earners may actually be paid more now than in the recent past, but their jobs are in many instances more informal and 
less secure. In these cases, workers' status has changed for the worse.

The middle stratum has also experienced decreased levels of welfare. This paper has described the negative effects of the compact on public-sector employment, and the ensuing effects on social stratification. It should also be added that the benefits of social policies have diminished, insofar as these policies have become more focused on the poor at the expense of middleincome groups. As a consequence, the middle classes now have less protection against unemployment and poor working conditions, public transfers (in the form of monetary benefits) have diminished and many occupations that hitherto provided them with status have either lost their social significance or disappeared altogether.

This unequal distribution of gains and losses seems even more regrettable in view of the high hopes being placed in the positive effects of globalization -a path to which all Latin American countries adhered from the early stages- on growth, equity and social integration. The issue, however, is how far globalization has brought additional distortions to an already unbalanced social situation. To place this in the right perspective, it should be recalled that the starting point from which globalization set out was not conducive to a process of social adjustment, since high income concentration and severe macroeconomic imbalances limited any positive effects that might have emerged from closer integration into the world economy. The analysis, then, should focus more on the post-adjustment situation.

As has been shown, there have been fundamental changes in the employment structure as well as in incomes and job quality. In most cases, people have found that the direction of change has been downward. Unemployment, a new feature of the situation, has also contributed to social exclusion, while volatility, which is associated with the workings of a more open economy, has brought instability in jobs and incomes. Unsurprisingly, the main fear of people in the region today is for their jobs, the chief concerns being instability and loss of labour protection. Demands for increased labour protection during times of adjustment have been thwarted by the need to husband resources, and particularly for Governments to correct fiscal imbalances.

Globalization has brought new dimensions to economic analysis of labour markets, given their increased links to trade, finance and communications at the international level. The old centre-periphery analysis, which has strongly influenced the Latin American in- tellectual tradition, is giving way to dependence and marginality analysis. Linkages today are not only closer but also of a different nature. Heterogeneity has increased.

A direct way of looking at this relationship is to identify population groups that are more closely linked to the global economy than to the country in which they live. A case that provides an interesting illustration of this situation is that of Mexico, which of all the countries in the region has perhaps been one of the most exposed to globalization in the recent past. Castañeda (1996) identifies four groups that are directly dependent on economic developments in the United States, totalling between them $20 \%$ to $25 \%$ of the Mexican population. Mexican migrants living in the United States are the first group. They constitute a source of income for an estimated 10 million Mexican residents; remittances, which have grown exponentially, are an important contribution to the budgets of poor families (it is estimated that in 1998 they totalled US\$ 5.5 billion, having tripled since 1990). A second group is involved with exports, including inbond assembly exports, which are produced by 2,500 establishments and benefit a further two million people, plus other export-related activities in agriculture and manufacturing industry. Several examples serve to illustrate this. General Motors of Mexico, the country's biggest private-sector exporter, sells $40 \%$ more cars abroad than in the domestic market. Corona, the main beer producer, sells one bottle abroad for each bottle that goes to the internal market, and Cementos Mexicanos exported $90 \%$ of its output in 1993. A third group whose livelihood depends on foreigners consists of those working in the tourism sector. It is estimated that 600,000 Mexicans are employed in this activity and hence insulated from fluctuations in the domestic economy. Lastly, a large number of people have links with foreign countries as legal or illegal property owners, or simply because they save, own assets, use financial instruments (like credit cards) or study or temporarily work abroad in professional and technical jobs.

Castañeda's analysis can be extended to the rest of Latin America, with different proportions involved but with similar types of relationships. Our own analysis shows, though, that not all sectors or all occupations within sectors have become global. The effects have not been homogeneous. Not all sectors have been equally affected, and within sectors the impact has been differentiated. Parts of industry have integrated into the world economy, while others have lagged behind; agroindustry, for instance, has established strong links with 
international markets, while traditional peasant agriculture has remained autonomous. Occupations have become more heterogeneous, both between and within sectors. This is particularly the case with the inbond assembly industry, tourism and subcontracting in manufacturing industry. Businesses and hence owners, managers, technicians and skilled labour are incorporated into the global economy; unskilled workers, while better off than before, are in an insecure position characterized by poor incomes, instability and lack of protection. Unemployment has added to social exclusion, particularly among women and young people.

Changes in the social structure have resulted from labour market effects; the differences between different population groups in the degree of global economic integration go beyond jobs and incomes to permeate social habits. Cultural and economic differences translate into different social behaviour. Urban life is increasingly segregated; there are now ghettos for the rich, as there have traditionally been for the poor. Closed areas, private security, exclusive malls and clubs and even schools conspire against social integration. Public spaces like parks and places of entertainment which encouraged social interaction in the past are less available. Separate schools divide children by social groups (Tokman and O'Donnell, eds., 1998). As O'Donnell (1998) puts it:
'The sharp, and deepening, dualism of our countries severely hinders the emergence of broad and effective solidarity. Social distances have increased, and the rich tend to isolate themselves from the strange and disquieting world of the dispossessed. The fortified ghettos of the rich and the secluded schools of their children bear witness to their incorporation into the transnationalized networks of modernity, as well as to the gulf that separates them from large segments of the national population.'

Social categories -as key instruments in the analysis of social stratification and social inclusion- are undergoing fundamental conceptual change. As Castañeda (1996) correctly argued, the issue today is not one of class, or ideology, or regions. It is not one of class, because the families of migrants or workers in some export sectors benefit as owners and managers do. It is not one of ideology, because ideas are now increasingly exposed and sustained by transnational events in what is a communications revolution. Nor is it a question of North against South, since the new economic situation and worldwide ideological change are blurring the divisions of the past. It goes beyond all this. Social groups are structured by occupations as they were in the past, but sectors tend to lose meaning when heterogeneity prevails and, more importantly, when people relate in a different way, culturally and economically, to national and international interests.

\section{Bibliography}

Atkinson, A.B. (1996): Income distribution in Europe and the United States, Oxford Review of Economic Policy, vol.12, No. 1, Oxford, U.K., Oxford University Press.

Bhagwati, J. and V. Dehejia (1993): Free trade and wages of the unskilled: Is Marx striking again?, J. Bhagwati and M. Kodsters (eds.), Trade and Wages, Washington, D.C., American Enterprise Institute.

Castañeda, J. (1996): The Estados Unidos affair. Cinco ensayos sobre un "amor" oblicuo, Mexico City, Aguilar.

ECLAC (Economic Commission for Latin America and the Caribbean) (1997a): The Equity Gap. Latin America, the Caribbean and the Social Summit, LC/G.1954/ Rev.1-P, Santiago, Chile. United Nations publication, Sales No. E.97.II.G.11.

(1997b): Stylized Facts of Income Distribution in Five Countries of Latin America and General Guidelines for a Redistributive Policy, Financiamiento del desarrollo series, No. 72, Santiago, Chile.

(1999): Social Panorama of Latin America, 1998, LC/ G.1892-P, Santiago, Chile.

Echeverría, R. (1985): Empleo público en América Latina, Investigaciones sobre empleo series, No. 26, Santiago,
Chile, Regional Employment Programme for Latin America and the Caribbean (PREALC).

Filgueira, C. and C. Geneletti (1981): Estratificación y movilidad ocupacional en América Latina, Cuadernos de la CEPAL, No. 39, Santiago, Chile, ECLAC.

Gitli, E. (1997): La industria de la maquila en Centroamérica. Informe para el Seminario Suregional de Empleadores de Centro América y República Dominicana, San José.

IDB (Inter-American Development Bank) (1998): América Latina frente a la desigualdad, Progreso económico y social en América Latina. Informe 1998-1999, Washington, D.C.

ILO (International Labour Organization) (1992): Report of the Director-General, Decimotercera Conferencia de los Estados de América Miembros de la Organización Internacional del Trabajo, Geneva.

(1995): World Employment 1995. An ILO Report, Geneva.

(1996): World Employment 1996/97: National Policies in a Global Context, Geneva.

(1997a): NEWS Latin America and the Caribbean 
1997 Labour Overview, Lima, ILO Regional Office for Latin America and the Caribbean.

(1997b): Chile: crecimiento, empleo y el desafío de la justicia social, Santiago, Chile, Multidisciplinary Technical Team.

(1998): NEWS Latin America and the Caribbean 1998 Labour Overview, Lima, ILO Regional Office for Latin America and the Caribbean.

Krugman, P. (1995): The Age of Diminished Expectation, Cambridge, Massachusetts, MIT Press.

Lawrence, R. and M. Slaughter (1993): International trade and American wages in the 1980s: Giant sucking sound or small hiccup?, Brookings Papers on Economic Activity, No. 2, Washington, D.C., The Brookings Institution.

Lustig, N. (1998): Pobreza y desigualdad: un desafío que perdura, CEPAL Review, special issue, LC/G.2037-P, Santiago, Chile, EClAC.

Meller, P. and A. Tokman (1996): Chile: apertura comercial, empleo y salarios, Working document, No. 38, Lima, ILO Regional Office for Latin America and the Caribbean.

OECD (Organisation for Economic Co-operation and Development) (1994): Perspectivas del empleo, The OECD Jobs study. Facts, analysis, strategies, Paris.

O'Donnell, G. (1998): Poverty and inequality in Latin America: Some political reflections, V. E. Tokman and G. O'Donnell (eds.): Poverty and Inequality in Latin America: Issues and New Challenges, Notre Dame, Indiana, University of Notre Dame.

Paes de Barros, R. and others (1996): Brasil: apertura comercial e mercado de trabalho, Working document, No. 39, Lima, ILO Regional Office for Latin America and the Caribbean.

Pérez-Sáinz, J. P. (1996): De la finca a la maquila, San José, Latin American Faculty of Social Sciences (FLACSO).
Saavedra, J. (1996): Perú: apertura comercial, empleo y salarios, Working document, No. 40, Lima, ILO Regional Office for Latin America and the Caribbean.

Sachs, J. and H. Shatz (1994): Trade and jobs in US manufacturing, Brookings Papers on Economic Activity, No. 1, Washington, D.C., The Brookings Institution.

Tokman, V.E. (1997): Jobs and solidarity: Main challenges for the post-adjustment Latin America, L. Emmerij (ed.), Economic and Social Development into the XXI Century, Washington, D.C., IDB.

(1998): Jobs and welfare: Searching for new answers, V.E. Tokman and G. O'Donnell (eds.), Poverty and Inequality in Latin America. Issues and New Challenges, Notre Dame, Indiana, University of Notre Dame.

(1999): The labour challenges of globalization and economic integration, E. Mayobre (ed.), G-24. The developing countries in the international financial system, Boulder, Colorado, Lynne Rienner Publishers.

Tokman, V.E. and D. Martínez (1999): Costo laboral y competitividad en el sector manufacturero de América Latina, 1990-1998, CEPAL Review, No. 69, LC/G.2067-P, Santiago, Chile, ECLAC.

Tokman, V.E. and D. Martínez (eds.) (1999): Flexibilización en el margen: la reforma del contrato de trabajo, Lima, ILO Regional Office for Latin America and the Caribbean.

Tokman, V.E. and G. O'Donnell (eds.) (1998): Poverty and Inequality in Latin America. Issues and New Challenges, Notre Dame, Indiana, University of Notre Dame.

Williamson, J. (1990): Latin American Ajustment: How Much has Happened?, Washington, D.C., Institute for International Economics (IIE).

Wood, A. (1994): North-South Trade, Employment and Inequality, Oxford, U.K., Clarendon Press. 